\title{
Delivery Mechanisms and Microenterprises Performance: An Analysis of Microcredit Program
}

\author{
Rosman Mahmood ${ }^{1}$, Ahmad Suffian Mohd Zahari ${ }^{1 *}$ \\ ${ }^{1}$ University of Technology MARA Terengganu, Dungun, Malaysia
}

\begin{abstract}
Purpose: The process of identifying and defining effective delivery mechanisms is a critical issue in the management of microcredit programs to meet the firm's objectives and the customers' needs. The purpose of this paper is to look at the relative importance of delivery mechanism in microcredit programs. In addition, this paper analyses the relationship between delivery mechanism and business performance among micro enterprises involved in microcredit programs. Methodology: The primary data of the study were obtained from 756 micro entrepreneurs under two major microcredit programs (AIM and TEKUN). Descriptive and t-test analysis were used to explain the findings of the study. Findings: Analysis of the study shows that cooperation from staff, the duration and method of loan repayment and monitoring of loan capital are important mechanism in the management of microcredit programs. T-test analysis revealed a significant difference in delivery mechanism between the two microcredit programs involved. Empirical findings show that the performance of micro enterprises under the AIM microcredit program is better than that of micro enterprises under the TEKUN microcredit program. Practical Implications: The performance of a microcredit program depends largely on their resource management. This involves operational efficiency, credit products offered, and customer support services. These three elements are critical factors in determining the effectiveness of the delivery mechanism in a microcredit program. Originality/value: The efficiency of delivery mechanisms through strategic resource management not only can enhance the competitive advantage of the AIM microcredit program but also affect the performance of the micro enterprises involved.
\end{abstract}

\section{Keywords:}

Delivery Mechanism;

Microcredit;

Micro Enterprises;

Operational Efficiency;

Credit Product;

Social Development Programs;

Performance.

Article History:

Received: 06 July 2020

Revised: $\quad 10 \quad$ May 2021

Accepted: 17 May 2021

Published: $01 \quad$ June 2021

\section{1- Introduction}

In an increasingly complex economic environment, the need for more innovative and competitive strategies is seen as crucial to achieving business objectives. The ability of a firm to achieve high levels of management efficiency depends on how they plan and manage their resources. These resources include physical, human capital and organizational resources [1,2]. Systematically planned resource management not only ensures the achievement of firm goals, generates added value [3], enhances competitive advantage and organizational performance [4] but can also have a significant impact on various stakeholders.

In the context of a microcredit program, the performance of the implementing agency depends largely on the delivery mechanism of the program in managing its resources. According to Gibbons \& Meehan (1999) and Yu et al. (2020) [5, 6] these competencies include labor and institutional operations that can be achieved through a variety of methods including, understanding customer requirements, using information management systems, establishing strategic planning and maintaining the quality of loan portfolio. These cover the aspects of operational efficiency (including staff

* CONTACT: Ahmadsuf@uitm.edu.my

DOI: http://dx.doi.org/10.28991/esj-2021-01281

(C) 2021 by the authors. Licensee ESJ, Italy. This is an open access article under the terms and conditions of the Creative Commons Attribution (CC-BY) license (https://creativecommons.org/licenses/by/4.0/). 
development), credit products (e.g. loan size, cost of borrowing, repayment period) and social development programs (such as training, exposure on business fundamental, guidance, supervision and project effectiveness, and customer services support). The efficiency of delivery mechanisms in microcredit programs not only can create competitive advantage, [7] maintain self-reliance without relying on financial assistance from the government but can also ensure the business performance of those involve with the program [8].

The process of identifying and deciding effective delivery mechanisms is a crucial issue for microcredit program management in ensuring that the program can be operate at a high level of efficiency to meet the firm's objectives and their customers' requirement. Although most microcredit programs are replicas of the Grameen Bank microcredit program, which is seen as a pioneer in the development of microcredit programs, they operate in accordance with local requirements. This is why each microcredit program has a different implementation approach for their delivery mechanism. These differences are seen as important elements that can influence the performance of a microcredit program.

Most studies on microcredit programs focus more on the impact of the program on the socioeconomic status of the target population. In addition, there are several case studies that focus on self-dependent issues among microcredit program institutions. On the other hand, not many studies have addressed issues related to the importance of mechanism of delivery and the effect of mechanism of implementation for each microcredit program on the performance of the small business that involved. The objective of this paper is to examine the relative importance of each delivery mechanism used in the microcredit program, to make a comparative analysis in terms of delivery mechanisms between the two micro-credit programs in Malaysia as well as to analyse the relationship between delivery mechanisms with the performance of micro enterprises. The findings of this study can not only provide useful guidance to organizations running microcredit programs but also contribute to the literature in the field, policy makers and entrepreneurs.

\section{2- Literature Review}

Microcredit program is an effort undertaken by various parties, including NGO's and government to help the poor to improve their standard of living through economic activity [9]. In addition to credit facilities, various support programs such as entrepreneurship and business training, technical assistance and social development inputs are also provided to enhance knowledge and skills among the target groups $[10,11]$. Nowadays microcredit program had evolved not only among developing and poor countries but also as a model for implementation in developed countries. Previous studies have clearly showed that microcredit programs had a significant impact on the performance of the micro enterprises that involved. These developments clearly indicate that the microcredit programs have become an important mechanism towards the growth of micro enterprises and the improvement of the standard of living of the poor.

The success of the microcredit programs is closely linked to the implementation efficiency of the delivery mechanism. Delivery mechanism refers to implementation processes, specifically the channels of reaching the clients and the savings and credit methodologies involved in extending the services to the clients. It is crucial that the delivery mechanism to be aligned with the target market, thus assisting in business strategy and performance achievements [12], [7]. In the context of micro credit program, the implementation of an efficient delivery mechanism is very important to enhance the management effectiveness and program supervision. The survival of the program and improvement of micro enterprise performance depends on the efficiency of micro credit program management of resources [13] and service delivery. Theory of Resource Based View (RBV) highlights the importance of internal resources in determining competitive advantage and firm performance. Based on the results of the discussion in the workshop "Bank Poor, 96", there are several important factors that can contribute to the degree of independence or performance of microcredit programs. These factors can be categorized into three elements namely credit products, operational efficiency and social development programs.

\section{2-1-Credit Product}

Credit products involve the aspect financial capital provided to customers. This element is essential to a microcredit program. According to a report, the "Bank Poor 96" product credit model has unique characteristics to attract customers, including the nature of products, easily obtainable, timely provision of credit, maturity and reasonable "grace period", smaller repayment instalments and; organized and affordable loan size $[5,14,15]$. In accordance with the Grameen Bank approach, the amount of credit granted will be increased by the loan. Studies conducted by Fatimah-Salwa et al. (2013) [16] demonstrate a growing number of loans granted have resulted in creating more successful microcredit programs and the enterprises involved. In addition to the loan repayment method, the success of microcredit programs also depends on the amount of loans issued [17, 18], loan interest [5] and approval [15]. Besides, there are several scholars that touched on the system adopted including the repayment of loans [19], the number of loans disbursed [16, 20] as well as the loan repayment period [19] and repayment rates [21] and cost control [5].

A study conducted by Seibel and Parhusip (1998) [22] on the microcredit program, Advancement Center for Agriculture Committee (CARD) in the Philippines found that performance achievable depends on the strength of credit 
discipline that covers the repayment method, timelines to refund, rise in the number of repeat loans and alternative arrangements to manage loan repayments. Most of the loans issued are in accordance with the approach practiced by Grameen Bank through group lending [23]. The management practices of credit products through group lending [24], as well as the schedule of repayment and flexible collateral [25] are perceived as the factors that determine the success of microcredit programs in developed countries [10]. Microcredit programs in the United States have different financing methods than that of developing countries. They do not lend by group, so they failed to utilize the benefits of the network [26] thus affecting the performance of the program and MSE's involved. On that account, microcredit programs in developed countries were less successful than those of developing countries [27]. For most programs such as the Grameen Bank microcredit replica, AIM participants are required to attend weekly meetings. Such approach turns out to be a very effective mechanism to guarantee the repayments by customers. In line the element of credit product, the success of microcredit were also contributed by other elements such as excess liquidity, deposit loan and interest rate [28], loan size, deposits volume, exchanges rates, lending rates, cash reserves rates, saving deposits rates [27, 29], system in credit product [30], variety of credit product, nature of credit products, easily obtainable, timely provision of credit, maturity and reasonable "grace period, and smaller repayment instalments [31]. This is supported by Seibel \& Parhusip (1998) and Christen (1997) [22, 30] who asserted that there is a positive relationship between credit products and performance.

\section{2-2-Operational Efficiency}

Operational efficiency also involves the organization's ability to manage resources utilization in a well-planned and effective manner. This includes the management of operations, strategic management, risk management, human resource development and savings mobilization [32].

The concept of operational efficiency encompasses the practice of improving all of your processes (all your company's activities that lead to your final product or service). Operational proficiency angle for microfinance part is a standout amongst the most essential viewpoints that must be considered by their administrations with a specific end goal to gain solid financial performances. According to Wheelock and Wilson (2010) [33] efficiency is the ability of management of the organizations to manage its operating costs in a most efficient manner through cost rationalization. It involves the process of allocating the available resources to viable investments. It can likewise be referred to as what happens when the right blend of individuals, process, and innovation meet up to improve the profitability and estimation of any business operation, while driving down the cost of routine operations to a desired level [5]. The importance of operational efficiency, particularly in the management of internal resources is also emphasized by Gibbons \& Meehan (1999) [5] in determining the performance of the microcredit program. A study conducted by Dokulilová et al. (2009) and Farrington (2000) $[34,35]$ also explore from the perspective of the importance of efficiency in the management of the microcredit program. Operational efficiency is necessary to achieve independent level and between major steps in the quest for independence in microcredit [5]. Furthermore, according to Gibbons \& Meehan (1999) [5], operational efficiency is an important factor in achieving self-reliance. The acceptable administrative efficiency is also vital for the survival of the microcredit program and the performance of MSEs [5]. For instance, Bhatt et al. (1999) [36] looked at some of the failure factors of microcredit programs in the United States, which are caused by laws manipulating over the interest rates charged to clients. Similarly, according to Salas-Velasco (2019) [37], management efficiency of microcredit enhances the efficiency level to achieve independent and financial levels of the organization. Meanwhile, technology and innovation efficiency has verifiably played an essential role in the business procedure change idea. It is considered by some as a noteworthy empowering agent for new types of working and teaming up within an association and crosswise over authoritative outskirts [38]. By and large, new innovation offers different sort of beneficial outcome to the organization. Therefore, innovation appropriation changes the customary method for working together by giving members totally new potential outcomes [39].

\section{2-3-Social Development Program}

Social development programs are the support efforts of the microcredit program executors including training, guidance and advice, customer support services, savings and monitoring and supervision activities. Microcredit programs such as AIM (Malaysia), K-REP (Kenya), Zambuko and PULSE (Zimbabwe) and GAF Stokvel (South Africa) are examples of microcredit programs that give special emphasis on training and mentoring. Training is important for applying entrepreneurial competency among customers. In fact, according to Light and Pham (1998), there is also a microcredit programs that requires prospective borrowers to sit and pass the training program held before the loan is issued to them. Involvement of operators in training and personal development programs will improve business management skills and provide a large space for increasing social capital in the business environment. They have the opportunity to reach out to various stakeholders including government agencies that provide assistance and support, competitors, customers and suppliers. Studies conducted by [31, 34, 40-51] also found that training and guidance is important in enhancing performance in microcredit and therefore is useful for microcredit in terms of high repayments rates and client retention. 
Sharma \& Zeller (1997) [52] have shown that there are various training activities in different areas such as entrepreneurial skill development, managing micro enterprises, shop keeping, crafts production, general awareness, family planning activities, and so forth. In addition to training and coaching, performance and customer microcredit programs also rely on the mandatory savings program. In addition to providing financial assistance, most microcredit programs also offer support services to improve the performance of the target groups. There are two main elements of focus in social development programs of entrepreneurship-monitoring and supervision. Target groups are not only facing capital constraints to operate a business, but also lack effective skills and knowledge in business management $[8,52]$. To overcome the shortcomings of the microcredit program, practitioners feel that customers should be exposed to the values and practices of entrepreneurship fundamentals in the business and also be motivated instead of solely participating in the provision of credit. Savings is regarded as a source of capital for production of loans to customers $[5,53]$, determinants of the microcredit survival program, performance of the MSEs, impact on the economy of the poor which includes the preparation of economic shocks and future ability to self-finance investment [54], and proliferation in the confidence of the poor [55]. Therefore, entrepreneurship development programs are treated as an important complementary factor to grant microcredit in improving performance.

\section{3- Research Methodology}

\section{3-1-Sample}

The research populations comprised of micro enterprises participants in microcredit program namely Amanah Ikhtiar Malaysia (AIM) and Tabung Kumpulan Usaha Niaga (TEKUN). Both microcredit programs were chosen because they have the highest number and the most active participants in Malaysia. The mechanism for implementing the AIM microcredit program is based on the Grameen Bank system in Bangladesh with some adaptation to local conditions. While TEKUN operates based on the AIM model. Most studies on microcredit in Malaysia used AIM and TEKUN as their sample. Meanwhile, the state of Kelantan was chosen because it was the earliest state in implementing the microcredit program as well as recording the highest number of participation in both programs. According to statistics during the study the number of participants in the AIM program, also known as "sahabat" was 30,446, while the TEKUN program consisted of 16,432 participants. Based on this population, Sekaran \& Bougie (2016) [56] proposes that the sample size for the study should be 380 (AIM) and 376 (TEKUN) respectively. The standard sampling method is used for data collection purposes. The population is divided into 10 districts in the state of Kelantan and the sample size for each strata is determined by the ratio of the strata population to the whole population.

Using the questionnaire as a research instrument, face-to-face interviews involving entrepreneurs of micro enterprises were conducted to obtain research information. The majority $(41.5 \%)$ of the business has been operated between 11 and 15 years old. They have less than 5 employees and an initial capital of less than RM5000. This explains that the majority of companies involved are micro enterprises. Most of them were involved in the retail sector (77\%) followed by the services sector $(16.7 \%)$ and manufacturing sector $(6.3 \%)$. A total of $63.5 \%$ made microcredit loans amounted less than RM6000. The main purpose of the loan is to grow their business. In addition to obtaining capital loans, they also benefited from various support programs including personal development (58.9\%), advisory services (42.9\%), moral support (42.3\%) and business training (12.8\%).

\section{3-2-Measurement}

\section{3-2-1- Microcredit Delivery Mechanism}

Delivery mechanism refers to the method of the implementation of microcredit programs. This includes credit product that is closely linked to financial loans provided and social development product that involved with delivery services and various support programs. Based on the literature review, this study considers 13 items that are important mechanisms in the implementation of microcredit programs. The items for microcredit delivery mechanism included in this study were costs charge on loan, time taken for loan approval, rules imposed, amount of loan disbursement, method of loan repayment, loan repayment period, monitoring of loan usage, personal development program, cooperation from the staff, monitoring and evaluation of business project, training / course offers, exposure to foundation of business, and provision of advisory services. In the survey, micro entrepreneurs were asked to rate the importance of each delivery mechanism items with a seven-point scale, ranging from 1 (strongly dissatisfied) to 7 (strongly satisfied).

\section{3-2-2- Microenterprises Performance}

The problem of availability and reliability of micro enterprise financial data has been a key factor for most researchers [57], to use subjective methods in performance measurement. This study also used the same method as a mechanism for measuring business performance. It involves a combination of performance assessment methods based on the importance of certain financial indicators such as profit realization, sales revenue, diversification of activities, market access, business growth as well as job creation opportunities [58]. There are 12 items used in performance measurement 
including sales revenue, profits, business stability, employment growth, reduction in cost of production, customer satisfaction, value of assets, market outreach and business networks. Based on the performance indicators listed, respondents were required to select their satisfaction level for the last three years based on a seven-point likert scale with a frequency of " 1 = strongly dissatisfied" to " 7 = strongly satisfied".

Based on the reliability test, Cronbach's Alpha values for the two variables used were 0.895 (business performance) and 0.816 (delivery mechanism). These values are higher than the lowest value (0.7) as stated by Nunnally (1978) [59], indicating their reliability to be used in the analysis.

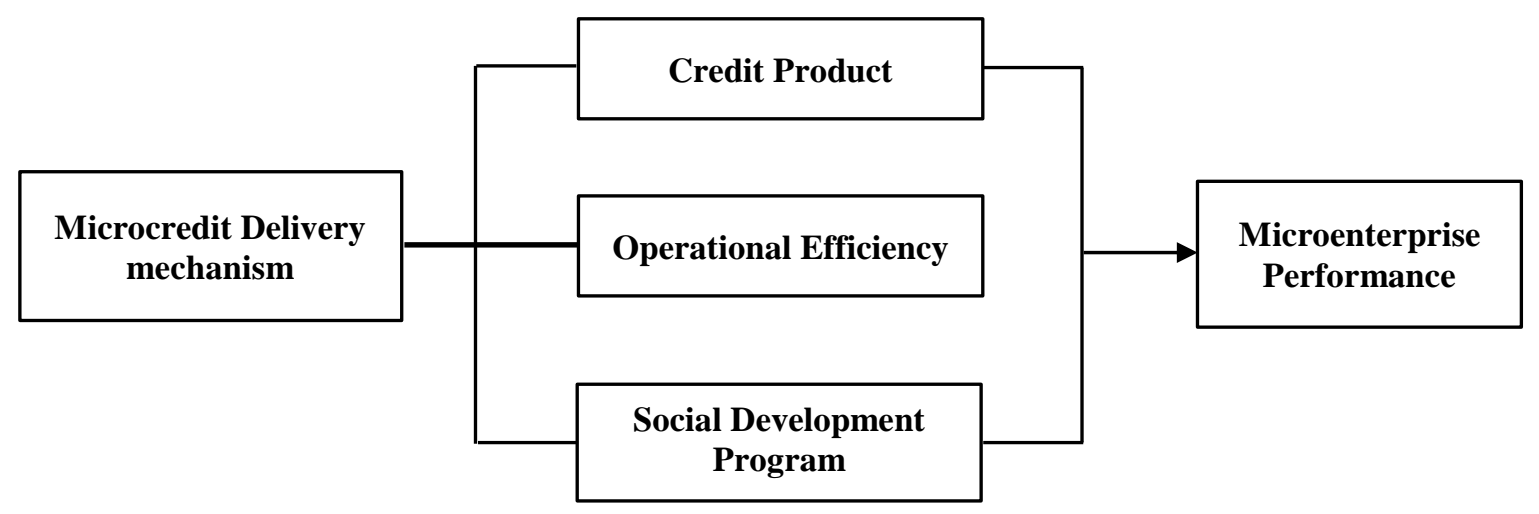

Figure 1. Conceptual Framework of Microcredit Delivery Mechanism and Microenterprise performance.

\section{4- Results}

\section{4-1- Relative Importance of Delivery Mechanism}

The rapid development of microcredit programs at the global level, particularly in terms of increasing number of institutions offering microcredit program and total participation among the poor clearly demonstrates that the program has the ability to conduct socio-economic shift to the target groups. The implementation of the program is not only a model for improving the lives of the target groups in poor and developing countries but also implemented in developed countries. Highlights of discussion among scholars in the field explain some of the important factors that can determine the impact of microcredit programs not only depend on the target groups as beneficiaries but also delivery mechanisms that are put into practice. Operational efficiency, credit product management and social development programs must be in line with the resources available, able to meet customers' needs and according to market needs. The uniqueness of the management of these three elements is an important factor that determines the effectiveness of delivery mechanisms for microcredit programs. The implementation of the strategic delivery mechanism can affect the performance of the micro enterprises involved. Table 1 shows the list of delivery mechanisms arranged according to the importance based on the mean value of the respondents' response. The analysis of the relative importance of each item of delivery mechanism was done according to the AIM and TEKUN microcredit programs and the overall sample.

For the AIM microcredit program, the highest satisfaction expressed by the respondent on the delivery mechanism was cooperation from the staff, followed by the method of loan repayment, loan repayment period, monitoring of loan use and amount of loan disbursement. Whereas low level of satisfaction involves training / course offered and exposure to foundation of business. For TEKUN programs, high levels of satisfaction include items of cooperation from the staff in addition to loan repayment period, method of loan repayment, monitoring of loan use and monitoring and evaluation of business project. The delivery mechanism under TEKUN also indicates a low level of satisfaction for personal development programs involving exposure to foundation of business and training / course offered. The analysis of the entire sample also showed that the cooperation of the staff was the most important factor, followed by several factors related to the operational efficiency of the loan repayment period and the method of loan repayment. In addition, respondents also pointed out the importance factor of monitoring of loan use, and monitoring and evaluation of business project. While the low level of satisfaction expressed by the respondents included time taken for loan approval, exposure to foundation of business as well as training and courses offered. These findings explain that the operational efficiency factor in the management of microcredit programs is the most important element to ensure the performance of micro enterprises. This is consistent with the findings of a study by [16, 22, 31, 34, 35, 40-51]. In this regard staff development programs need to be given priority to ensure that they understand their responsibilities and role in performing the tasks and meeting customer requirements. 


\section{4-2- Comparison of Delivery Mechanism}

In total, the comparative analysis of the delivery mechanism between AIM and TEKUN microcredit programs involved with the 13 items shown in Table 2. Based on the seven-point likert scale, the AIM microcredit program shows that there are six items with a mean value of more than five, while the remaining seven have a mean value of less than five. For the TEKUN program, there are two items (Cooperation from the staff of loan provider and loan repayment period) that indicate a mean value of more than five, while another 11 items indicate a mean value lower than that. By comparison, the delivery mechanism under the AIM microcredit program shows higher mean value in 12 items than just one item of delivery mechanism (exposure to foundation of business) for the TEKUN microcredit program. T-test analysis revealed that there are eight items had significant differences in terms of delivery mechanism between the two programs. The items were amount of loan disbursement $(\mathrm{t}=5.68, \mathrm{p}<0.01)$, cooperation from the staff of loan provider $(\mathrm{t}=5.44, \mathrm{p}<0.01)$, monitoring and evaluation of business project $(\mathrm{t}=4.23, \mathrm{p}<0.01)$, provision of advisory services $(\mathrm{t}=$ $3.85, \mathrm{p}<0.01)$, monitoring of loan use $(\mathrm{t}=3.84, \mathrm{P}<0.01)$, method of loan repayment $(\mathrm{t}=2.35, \mathrm{p}<0.05)$, cost $/$ services charge on loan $(\mathrm{t}=1.92, \mathrm{P}<0.1)$ and loan repayment period $(\mathrm{t}=1.70, \mathrm{P}<0.1)$. Only five items, namely rules / conditions imposed on loan, personal development programs, the time taken for loan approval, exposure to the foundation of business and training / course offer which shows no significant difference between the two programs. The analysis of the study also shows that the mean value of the delivery mechanism for the AIM microcredit program (4.96) is higher than the mean value of the overall delivery mechanism for the TEKUN program (4.75). According to the $t$-test $(t=4: 34$, $\mathrm{p}<0.01$ ) clearly shows there are significant differences in terms of delivery mechanisms between the two programs.

\section{4-3- Comparison of Performance by Microcredit Program}

The difference in delivery mechanism will not only affect the competitive advantage of the institution that implement microcredit program but also the performance of the small enterprises involved. Table 3 shows the performance comparison analysis between AIM and TEKUN microcredit programs. For the AIM program all items showed a mean value of more than five except for increase in item number of workers (4.62). The highest mean for the AIM program is indicated by the item sales revenue (5:49). Whereas for the TEKUN micro credit program, six items have a mean value of five while another six items have a mean value of less than five. The highest mean value for the TEKUN program involved customer satisfaction item (5.21) and the lowest mean value is for reduce production costs item (4.51). The analysis of the study clearly shows that the overall mean value of micro enterprises' performance under AIM microcredit program (5.18) is higher than the micro enterprises' performance under TEKUN program (4.97).

By comparison, out of the 12 performance measurement items involved, the AIM microcredit program showed higher mean value in 11 items compared to only one item in the TEKUN microcredit program (increased number of workers). Based on the t-test, the study found that 10 items showed significant differences in performance between small firms under AIM and TEKUN. The most significant difference was for reduce production costs item $(t=6.46, p<0.01)$. Other items that indicated significant differences between the two microcredit programs were sales revenue $(\mathrm{t}=4.24, \mathrm{p}<0.01)$, market breadth $(\mathrm{t}=4.03, \mathrm{p}<0.01)$, the value of asset $(\mathrm{t}=3.64, \mathrm{p}<0.01)$, meet market needs $(\mathrm{t}=3.17, \mathrm{p}<0.01)$, business stability $(\mathrm{t}=2.80, \mathrm{p}<0.01)$, business network $(\mathrm{t}=2.48, \mathrm{p}<0.05)$, business growth $(\mathrm{t}=2.22, \mathrm{p}<0.05)$, customer satisfaction $(\mathrm{t}=2.18, \mathrm{p}<0.05)$ and contribute to community $(\mathrm{t}=1.99, \mathrm{p}<0.05)$. Only two items, namely profit earned and increased number of workers, did not show significant differences between the two microcredit programs. The t-test analysis revealed significant differences in performance $(t=4.23, \mathrm{p}<0.01)$ between the small enterprises of the two programs. Based on the mean value of the performance measurement in the findings of the study, it can be concluded that the performance of small enterprises under the AIM microcredit program is better than the small enterprises under the TEKUN microcredit program. 
Table 1. Relative importance of delivery mechanism in microcredit programs.

\begin{tabular}{|c|c|c|c|c|c|c|c|c|}
\hline \multicolumn{3}{|c|}{$\operatorname{AIM}(n=380)$} & \multicolumn{3}{|c|}{ TEKUN $(n=376)$} & \multicolumn{3}{|c|}{ All samples $(n=756)$} \\
\hline Rank & Criteria of delivery mechanism & Mean $^{\text {a }}$ & Rank & Criteria of delivery mechanism & Mean $^{\text {a }}$ & Rank & Criteria of delivery mechanism & Mean $^{\text {a }}$ \\
\hline 1 & Cooperation from the staff of loan provider & 5.61 & 1 & Cooperation from the staff of loan provider & 5.18 & 1 & Cooperation from the staff of loan provider & 5.40 \\
\hline 2 & Method of loan repayment & 5.15 & 2 & Loan repayment period & 5.02 & 2 & Loan repayment period & 5.08 \\
\hline 3 & Loan repayment period & 5.14 & 3 & Method of loan repayment & 4.98 & 3 & Method of loan repayment & 5.06 \\
\hline 4 & Monitoring of loan use & 5.13 & 4 & Monitoring of loan use & 4.88 & 4 & Monitoring of loan use & 5.01 \\
\hline 5 & Amount of loan disbursement & 5.13 & 5 & Monitoring and evaluation of business project & 4.82 & 5 & Monitoring and evaluation of business project & 4.96 \\
\hline 6 & Monitoring and evaluation of business project & 5.11 & 6 & Rules/conditions imposed on loan & 4.80 & 6 & Amount of loan disbursement & 4.89 \\
\hline 7 & Rules/conditions imposed on loan & 4.91 & 7 & Personal development program & 4.69 & 7 & Rules/conditions imposed on loan & 4.85 \\
\hline 8 & Provision of advisory services & 4.87 & 8 & Amount of loan disbursement & 4.65 & 8 & Personal development program & 4.72 \\
\hline 9 & Cost/service charge on loan & 4.78 & 9 & Time taken for loan approval & 4.65 & 9 & Provision of advisory services & 4.71 \\
\hline 10 & Personal development program & 4.75 & 10 & Cost/service charge on loan & 4.56 & 10 & Cost/service charge on loan & 4.67 \\
\hline 11 & Time taken for loan approval & 4.67 & 11 & Provision of advisory services & 4.55 & 11 & Time taken for loan approval & 4.66 \\
\hline 12 & Training/course offer & 4.47 & 12 & Exposure to foundation of business & 4.43 & 12 & Exposure to foundation of business & 4.42 \\
\hline 13 & Exposure to foundation of business & 4.41 & 13 & Training/course offer & 4.34 & 13 & Training/course offer & 4.40 \\
\hline
\end{tabular}

Table 2. Comparison between AIM and TEKUN microcredit program.

\begin{tabular}{lccccc}
\hline \multirow{2}{*}{\multicolumn{1}{c}{ Delivery mechanism }} & \multicolumn{2}{c}{ AIM $(\boldsymbol{n = 3 8 0})$} & \multicolumn{2}{c}{ TEKUN $(\boldsymbol{n}=\mathbf{3 7 6})$} & \multirow{2}{*}{-stat } \\
\cline { 2 - 5 } & Standard Deviation & Mean $^{\text {a }}$ & Standard Deviation & Mean $^{\text {a }}$ & \\
\hline Cooperation from the staff of loan provider & 1.02 & 5.61 & 1.14 & 5.18 & $5.442^{* * * *}$ \\
Loan repayment period & 0.81 & 5.14 & 1.05 & 5.02 & $1.695^{*}$ \\
Method of loan repayment & 0.82 & 5.15 & 1.13 & 4.98 & $2.354^{* * *}$ \\
Monitoring of loan use & 0.81 & 5.13 & 1.02 & 4.88 & $3.839^{* * * *}$ \\
Monitoring and evaluation of business project & 0.87 & 5.11 & 1.03 & 4.82 & $4.233^{* * *}$ \\
Amount of loan disbursement & 0.92 & 5.13 & 1.34 & 4.65 & $5.684^{* * *}$ \\
Rules/conditions imposed on loan & 1.33 & 4.91 & 1.44 & 4.80 & 1.013 \\
Personal development program & 1.14 & 4.75 & 1.21 & 4.69 & 0.686 \\
Provision of advisory services & 1.07 & 4.87 & 1.20 & 4.55 & $3.852^{* * *}$ \\
Cost/ services charge on loan & 1.54 & 4.78 & 1.61 & 4.56 & $1.922^{*}$ \\
Time taken for loan approval & 1.30 & 4.67 & 1.46 & 4.65 & 0.194 \\
Exposure to foundation of business & 1.54 & 4.41 & 1.27 & 4.43 & 0.172 \\
Training/course offer & 1.36 & 4.47 & 1.31 & 4.34 & 1.396 \\
Roles of the overall program & 0.87 & 4.96 & 1.24 & 4.75 & $4.336^{* * *}$ \\
\hline
\end{tabular}

Notes: significant at: $* 0.10, * * 0.05$ and $* * * 0.01,{ }^{a}$ with a seven-point scale

Source: Based on the sample survey 
Table 3. Comparison of Performance by Microcredit Program.

\begin{tabular}{lccc}
\hline \multirow{2}{*}{ Micro Enterprise Performance } & \multicolumn{2}{c}{ Mean } & \multirow{2}{*}{$\boldsymbol{t}$ - test } \\
\cline { 2 - 3 } & AIM $(\mathbf{N}=\mathbf{3 8 0})$ & TEKUN $(\mathbf{N}=\mathbf{3 7 6})$ & \multirow{2}{*}{$4.240^{* * *}$} \\
\hline Sales revenue & 5.49 & 5.19 & 1.109 \\
Profit earned & 5.21 & 5.13 & $2.799 * * *$ \\
Business stability & 5.29 & 4.93 & $1.992^{* * *}$ \\
Contribute to community & 5.08 & 5.00 & $3.166^{* * *}$ \\
Meet market needs & 5.23 & 4.93 & $2.223^{* *}$ \\
Business growth & 5.09 & 4.74 & -1.311 \\
Increased number of workers & 4.62 & 4.51 & $6.464 * * *$ \\
Reduce production costs & 5.04 & 5.21 & $2.177^{* *}$ \\
Customer satisfaction & 5.37 & 4.88 & $4.028^{* * *}$ \\
Market breadth & 5.18 & 4.92 & $3.639 * * *$ \\
The value of assets (current and fixed) & 5.19 & 5.02 & $2.482^{* * *}$ \\
Business Network & 5.20 & 4.97 & $4.230^{* * *}$ \\
Overall mean value & 5.18 & & 5 \\
\hline
\end{tabular}

Notes: Significant at: $* 0.10, * * 0.05$ and $* * * 0.01,{ }^{a}$ with a seven-point scale

Source: Based on the sample survey

\section{5- Discussion}

The objective of this article is to explain the relative importance of various delivery mechanisms used in the management of microcredit programs, to analyse the comparative performance of delivery mechanisms between the two microcredit programs and to see the relationship between delivery mechanisms and the performance of the micro enterprises involved. The study data is derived from a survey of 756 small enterprises involved in two of the most active microcredit programs in Malaysia today.

Based on the analysis of the relative importance of the microcredit program delivery mechanism, the findings show that there is no clear difference in the relative importance of the delivery mechanism between the two microcredit programs involved. Some items reach a high level of satisfaction including cooperation from staff, loan repayment period, method of loan repayment and monitoring of loan use. While other mechanisms such as time taken for loan approval, exposure to foundation of business and course / training offer show low levels of satisfaction. These findings suggest that microcredit programs focus more on operations and credit product management but less on social development programs such as training and exposure to business and entrepreneurship fundamentals. This is consistent with a study by [8] who described small entrepreneurs under both programs as less involved in training and mentoring programs. In fact, their propensity for training and mentoring programs is too low. That is why the factor is seen as insignificant with the performance of the small enterprises involved. According to Chinomona (2013) [43], exposure to training and mentoring programs are critical factors in determining business performance.

In comparison there are six mechanisms under the AIM microcredit program showing a high degree of satisfaction (mean value exceeds five) compared to only two mechanisms under the TEKUN microcredit program. Empirically the study explains that there are eight mechanisms that show significant differences between the two microcredit programs. All eight of these mechanisms are dominated by the AIM microcredit program. Only five mechanisms do not show differences in implementation between the two microcredit programs. Based on the role of the whole program the empirical evidence shows that there are differences between the two microcredit programs. Accordingly, the study summarizes the delivery mechanism under AIM is better than what is practiced by TEKUN.

The performance measurement mechanism under the AIM microcredit program showed a higher level of satisfaction in 11 items compared to only one item in the TEKUN microcredit program. Empirically the study found 10 items of performance indicators that significantly explain the differences in performance that exist between the two microcredit programs. Only two items (profit earned and increased number of workers) showed no differences. Based on empirical evidence of the overall mean value, the study concluded that the performance of micro enterprises under the AIM microcredit program is better than that of micro enterprises under the TEKUN microcredit program. The AIM microcredit program demonstrates improved viability through high self-reliance and high loan repayment rates. Through the implementation of strategies that involve the exploitation of its resources, internal strengths, the environment, neutralizing external threats and avoiding internal weaknesses [1] is a key factor in the implementation of delivery mechanisms under the AIM microcredit program. The high degree of satisfaction with the mechanism of delivery under the AIM microcredit program clearly indicates that there is a more strategic management of resources within the 
microcredit program as described in the Resource-based View Theory (RBV). The uniqueness of the delivery mechanism through the strategic management of these resources not only enhances the competitive advantage of the AIM microcredit program but also affects the performance of the micro enterprises involved.

\section{6- Conclusion}

Based on these findings, the study proposes microcredit programs to focus on several important aspects to ensure improvement in existing delivery mechanisms. This is important to ensure the effectiveness of the microcredit program and the performance of the small businesses involved. These measures include increasing the amount of loans provided to small enterprises with satisfactory repayment records, more flexible loan repayments to increase liquidity in the financial management of small enterprises, imposing more favourable conditions, facilitating more transparent supervision of the use of loan capital to prevent leaks and capital misuse and to emphasize self-development programs to strengthen business fundamentals and create high entrepreneurial traits among small business owners.

This study only considers some of the delivery mechanisms involved in microcredit programs. In a broader context, there are several other mechanisms that can be included in the study, including those related to saving mobilization, insurance, participant selection, and program information delivery. In terms of performance measurement, the study only considers economic indicators without regard to social aspects such as quality of life, household spending, and dependency education. Accordingly, for further research it is proposed that performance measures include more comprehensive elements in the socio-economic aspects. This can provide a clearer picture of the performance of the microcredit program and the target groups involved.

\section{7- Declarations}

\section{7-1-Author Contributions}

Conceptualization, R.M., and A.S.M.Z.; writing — original draft preparation, R.M., A.S.M.Z.; writing — review and editing. All authors have read and agreed to the published version of the manuscript.

\section{7-2-Data Availability Statement}

The data presented in this study are available in article.

\section{7-3- Funding}

The authors received no financial support for the research, authorship, and/or publication of this article.

\section{7-4- Conflicts of Interest}

The authors declare that there is no conflict of interests regarding the publication of this manuscript. In addition, the ethical issues, including plagiarism, informed consent, misconduct, data fabrication and/or falsification, double publication and/or submission, and redundancies have been completely observed by the authors.

\section{8- References}

[1] Barney, Jay. "Firm Resources and Sustained Competitive Advantage.” Journal of Management 17, no. 1 (March 1991): 99-120. doi:10.1177/014920639101700108.

[2] Collins, Christopher J. "Expanding the Resource Based View Model of Strategic Human Resource Management." The International Journal of Human Resource Management 32, no. 2 (January 10, 2020): 331-358. doi:10.1080/09585192.2019.1711442.

[3] Santos-Rodrigues, Helena, Pedro Figueroa Dorrego, and Carlos Fernandez Jardon. "The Influence of Human Capital on the Innovativeness of Firms.” International Business \& Economics Research Journal (IBER) 9, no. 9 (December 20, 2010): 53-63. doi:10.19030/iber.v9i9.625

[4] Kamukama, Nixon, Augustine Ahiauzu, and Joseph M. Ntayi. "Competitive Advantage: Mediator of Intellectual Capital and Performance.” Journal of Intellectual Capital 12, no. 1 (January 18, 2011): 152-164. doi:10.1108/14691931111097953.

[5] Gibbons, David S., and Jennifer W. Meehan. "The microcredit summit's challenge: Working toward institutional financial selfsufficiency while maintaining a commitment to serving the poorest families." Journal of Microfinance/ESR Review 1, no. 1 (1999): 131-192.

[6] Yu, Jie, Xiao Han, Baozhen Chen, and Jinzheng Ren. "Estimating the Impact of Poverty Alleviation Microcredit on the Income of Poor Households Using the Propensity Score Matching Method: Evidence from China.” Agriculture 10, no. 7 (July 14, 2020): 293. doi:10.3390/agriculture10070293. 
[7] Prathap, B. N., K. C. Subrahmanya, and B. S. Harisha. "Microfinance Delivery - Challenges and Remedies.” International Journal of Management Studies V, no. 3(9) (July 1, 2018): 138-144. doi:10.18843/ijms/v5i3(9)/17..

[8] Mahmood, Rosman, and M. Mohd Rosli. "Microcredit Position in Micro and Small Enterprise Performance: The Malaysian Case." Management Research Review 36, no. 5 (April 19, 2013): 436-453. doi:10.1108/01409171311327226.

[9] Zheng, Chen, and Junru Zhang. "The Impact of COVID-19 on the Efficiency of Microfinance Institutions.” International Review of Economics \& Finance 71 (January 2021): 407-423. doi:10.1016/j.iref.2020.09.016.

[10] McKernan, Signe-Mary. "The Impact of Microcredit Programs on Self-Employment Profits: Do Noncredit Program Aspects Matter?" Review of Economics and Statistics 84, no. 1 (February 2002): 93-115. doi:10.1162/003465302317331946.

[11] Duasa, Jarita, and Nur Hidayah Zainal. "Determinants of Household Income of Micro-Finance Women Participants: a Quantile Regression Approach.” Ecofeminism and Climate Change 1, no. 1 (June 1, 2020): 63-74. doi:10.1108/efcc-03-2020-0002.

[12] Ponsignon, F., P.A. Smart, and R.S. Maull. "Service Delivery System Design: Characteristics and Contingencies.” Edited by Patrik Jonsson. International Journal of Operations \& Production Management 31, no. 3 (February 22, 2011): $324-349$. doi:10.1108/01443571111111946.

[13] Painter, Gary, and Shui-Yan Tang. "The microcredit challenge: A survey of programs in California." Journal of Developmental Entrepreneurship 6, no. 1 (2001): 1-16.

[14] Olabamiji, Ogunlade, and Oseni Michael. "Credit Management Practices and Bank Performance: Evidence from First Bank." South Asian Journal of Social Studies and Economics (April 19, 2018): 1-10. doi:10.9734/sajsse/2018/v1i125772.

[15] Ravicz, R. Marisol. "Searching for Sustainable Microfinance: A Review of Five Indonesian Initiatives." Policy Research Working Papers (November 30, 1999). doi:10.1596/1813-9450-1878.

[16] Fatimah-Salwa, A. H., A. Mohamad-Azahari, and B. Joni-Tamkin. "Success factors of successful microcredit entrepreneurs: Empirical evidence from Malaysia." International journal of Business and Social science 4, no. 5 (2013): 153-159.

[17] Ogunsanwo, Odunayo Femi, Rasheed Alade Abdulai, and Mojisola Abere. "Effects of Credit Policies on Delinquency Management of Microfinance Banks in Southwest, Nigeria.” International Journal of Academic Research in Business and Social Sciences 10, no. 5 (May 12, 2020): 456-470. doi:10.6007/ijarbss/v10-i5/7216.

[18]Pereira, Sofia, and Paulo Mourao. "Why Does the Microcredit Borrowing Rate Differ Across Countries? A Cross-country Study." International Journal of Social Economics 39, no. 8 (June 29, 2012): 536-550. doi:10.1108/03068291211238428.

[19] Derban, William K., Jane M. Binner, and Andy Mullineux. "Loan Repayment Performance in Community Development Finance Institutions in the UK." Small Business Economics 25, no. 4 (November 2005): 319-332. doi:10.1007/s11187-004-6483-y.

[20] Obamuyi, Tomola M. “Credit Delivery and Sustainability of Micro - credit Schemes in Nigeria.” Edited by Garth Cant. Journal of Enterprising Communities: People and Places in the Global Economy 3, no. 1 (March 27, 2009): 71-83. doi:10.1108/17506200910943689.

[21] Ibn Boamah, Mustapha, and Jasmine Alam. "Canadian Micro-Credit Programs: An Investigation of Model Differences.” Journal of Small Business \& Entrepreneurship 28, no. 4 (June 8, 2016): 307-324. doi:10.1080/08276331.2016.1189685.

[22] Seibel, Hans Dieter, and Uben Parhusip. "Attaining Outreach with Sustainability: A Case Study of a Private Micro-Finance Institution in Indonesia.” IDS Bulletin 29, no. 4 (October 1998): 81-90. doi:10.1111/j.1759-5436.1998.mp29004009.x.

[23] Estapé-Dubreuil, Glòria, and Consol Torreguitart-Mirada. "Microfinance and Gender Considerations in Developed Countries." Management Research Review 33, no. 12 (November 15, 2010): 1140-1157. doi:10.1108/01409171011092194.

[24] Rubach, Michael J., Don B. Bradley III, and Justin Eric Brown. "The determinants of the success of microlending: A comparison of Iraq and the United States." International Journal of Entrepreneurship 14 (2010): 59-70.

[25] Armendáriz, Beatriz, and Jonathan Morduch. “The Economics of Microfinance.” MIT Press, (2010).

[26] Richardson, Molly. "Increasing Microlending Potential in the United States through a Strategic Approach to Regulatory Reform." Journal of Corporation Law 34 (2008): 923-942.

[27] Hung, C. R. "From south to north: A comparative study of microcredit programs in developing and developed countries." In 21st Annual Research Conference of the Association for Public Policy Analysis and Management, November, (1999): 4-6.

[28] Sainz-Fernandez, Isabel, Begoña Torre-Olmo, Carlos López-Gutiérrez, and Sergio Sanfilippo-Azofra. "Crisis in Microfinance Institutions: Identifying Problems.” Journal of International Development 27, no. 7 (August 7, 2015): 1058-1073. doi:10.1002/jid.3129.

[29] McNamara, Nora, and Stephen Morse. "Donors and Sustainability in the Provision of Financial Services in Nigeria." IDS Bulletin 29, no. 4 (October 1998): 91-101. doi:10.1111/j.1759-5436.1998.mp29004010.x.

[30] Christen, R. P. "Banking services for the poor: Managing for financial success: An expanded and revised guidebook for microfinance institutions." Somerville: ACCION International, (1997). 
[31] Getubig, Ismael P., J. V. Remenyi, and B. Quinones. "Creating the Vision: Microfinancing the Poor in Asia-Pacific: Issues, Constraints, and Capacity-building.” Asian and Pacific Development Centre, Kuala Lumpur, Malaysia, (1997): 127.

[32] Nourani, Mohammad, Nurhafiza Abdul Kader Malim, and Md Aslam Mia. "Revisiting Efficiency of Microfinance Institutions (MFIs): An Application of Network Data Envelopment Analysis.” Economic Research-Ekonomska Istraživanja 34, no. 1 (September 19, 2020): 1146-1169. doi:10.1080/1331677x.2020.1819853.

[33] Wheelock, David C., and Paul W. Wilson. "The Evolution of Cost-Productivity and Efficiency among U.S. Credit Unions." SSRN Electronic Journal (November 2010): 75-88. doi:10.2139/ssrn.1359349.

[34] Dokulilová, Lenka, Karel Janda, and Pavel Zetek. “Sustainability of Microfinance Institutions in Financial Crisis.” European Financial and Accounting Journal 4, no. 2 (June 1, 2009): 7-33. doi:10.18267/j.efaj.65.

[35] Farrington, Todd. "Efficiency in microfinance institutions." MicroBanking Bulletin 4, no. 1 (2000): 18-23.

[36] Bhatt, Nitin, Gary Painter, and T. A. N. G. Shui-Yan. "Can microcredit work in the United States?" Harvard Business Review 77, no. 6 (1999): 26-27.

[37] Salas-Velasco, Manuel. "The Technical Efficiency Performance of the Higher Education Systems Based on Data Envelopment Analysis with an Illustration for the Spanish Case.” Educational Research for Policy and Practice 19, no. 2 (November 2, 2019): 159-180. doi:10.1007/s10671-019-09254-5.

[38] Harry, Mikel, and Richard Schroeder. "Summary: Six Sigma: Review and Analysis of Harry and Schroeder's Book." Currency (2006).

[39] Peppard, Joe, and Philip Rowland. “The essence of business process re-engineering.” New York: Prentice-Hall Editions, (1995).

[40] Dalla Pellegrina, Lucia, Giorgio Di Maio, Paolo Landoni, and Emanuele Rusinà. "Money Management and Entrepreneurial Training in Microfinance: Impact on Beneficiaries and Institutions." Economia Politica (February 4, 2021). doi:10.1007/s40888021-00217-9.

[41] Roslan, Abdul H., and Mohd ZA Karim. "Determinants of microcredit repayment in Malaysia: The case of Agrobank." Humanity \& Social Sciences Journal 4, no. 1 (2009): 45-52.

[42] García, Mercedes Úbeda. "Training and Business Performance: The Spanish Case.” The International Journal of Human Resource Management 16, no. 9 (September 2005): 1691-1710. doi:10.1080/09585190500239341.

[43] Chinomona, Richard. "Business owner's expertise, employee skills training and business performance: A small business perspective." Journal of Applied Business Research (JABR) 29, no. 6 (2013): 1883-1896. doi:10.19030/jabr.v29i6.8224.

[44] Tax, Stephen S., and Ian Stuart. "Designing and Implementing New Services: The Challenges of Integrating Service Systems." Journal of Retailing 73, no. 1 (March 1997): 105-134. doi:10.1016/s0022-4359(97)90017-8.

[45] Aragón-Sánchez, Antonio, Isabel Barba-Aragón, and Raquel Sanz-Valle. "Effects of Training on Business Results1." The International Journal of Human Resource Management 14, no. 6 (September 2003): 956-980. doi:10.1080/0958519032000106164.

[46] Zinger, J. Terence, Rolland LeBrasseur, and Louis R. Zanibbi. "Factors influencing early stage performance in Canadian microenterprises." Journal of Developmental Entrepreneurship 6, no. 2 (2001): 129-150.

[47] Ang, Mei Hwa. "Empowering the Poor through Microcredit." International Journal of Entrepreneurship and Innovation Management 4, no. 5 (2004): 485-494. doi:10.1504/ijeim.2004.005756.

[48] Anku-Tsede, Olivia. "Microfinance Intermediation: Regulation of Financial NGOs in Ghana." International Journal of Law and Management 56, no. 4 (July 8, 2014): 274-301. doi:10.1108/ijlma-07-2012-0025.

[49] Alam, Saad. "The Impact of Credit and Non-Credit Aspects on Self-Employment Profit: A Comparison of Microcredit Programs and Commercial Lenders in Rural Bangladesh." The Journal of Developing Areas 47, no. 1 (March 2013): 23-45. doi:10.1353/jda.2013.0018.

[50] Berko, Lili, and Agota Gueullette. "Policy for Support of Small and Medium-Size Enterprises in Hungary: The Case of the Central Region.” Post-Communist Economies 15, no. 2 (June 2003): 243-257. doi:10.1080/14631370308096.

[51] Fraser, Stuart, David Storey, Julian Frankish, and Richard Roberts. "The Relationship between Training and Small Business Performance: An Analysis of the Barclays Bank Small Firms Training Loans Scheme.” Environment and Planning C: Government and Policy 20, no. 2 (April 2002): 211-233. doi:10.1068/c0111.

[52] Sharma, Manohar, and Manfred Zeller. "Repayment Performance in Group-Based Credit Programs in Bangladesh: An Empirical Analysis.” World Development 25, no. 10 (October 1997): 1731-1742. doi:10.1016/s0305-750x(97)00063-6.

[53] Awaworyi Churchill, Sefa. "Microfinance Financial Sustainability and Outreach: Is There a Trade-Off?" Empirical Economics 59, no. 3 (May 14, 2019): 1329-1350. doi:10.1007/s00181-019-01709-1.

[54] Berg, Gunhild. "Evaluating the impacts of microsaving: The case of Sewa Bank in India." Journal of Economic Development 35 (March 2010): 75-96. 
[55] Singh, Sri Ram. "Micro finance programmes in India-An overview." Anusandhanika 4, no. 2 (July 2012): 23-30.

[56] Sekaran, Uma, and Roger Bougie. "Research Methods for Business: A Skill Building Approach.” John Wiley \& Sons, (2016).

[57] Swinney, Jane L., Rodney C. Runyan, and Patricia Huddleston. "Differences in Reported Firm Performance by Gender: Does Industry Matter?” Journal of Developmental Entrepreneurship 11, no. 2 (June 2006): 99-115. doi:10.1142/s1084946706000350.

[58] Amrani, Mohamed BS, and Faris Hamza. "A Modeling Study of the Micro-finance İmpact on the Economic Performance of Micro-enterprises and the Well-being of Borrowers in Morocco: Case of Tangier-Tetouan-Al Hoceima Region." International Journal of Economics and Financial Issues 8, no. 5 (2018): 243-250.

[59] Nunnally, J. C. "Psychometric theory." (2nd ed.). New York: McGraw-Hill. (1978). 